\title{
MECHANICAL PROPERTIES OF A NOVEL JOINT OF A SINGLE-LAYER ALUMINUM-ALLOY COMBINED LATTICE-SHELL STRUCTURE
}

\author{
MEHANSKE LASTNOSTI NOVEGA SPOJA IZ ENE PLASTI \\ ALUMINIJEVE ZLITINE KOMBINIRANE MREŽNO-LUPINASTE \\ STRUKTURE
}

\author{
Caiqi Zhao*, Jun Ma, Shengchen Du, Ye Gu, Yunwen Zhou \\ Key Laboratory of Concrete and Prestressed Concrete Structures, Ministry of Education, School of Civil Engineering, Southeast University, \\ Nanjing 210096, China \\ Prejem rokopisa - received: 2019-02-01; sprejem za objavo - accepted for publication: 2019-06-17
}

doi:10.17222/mit.2019.031

\begin{abstract}
To overcome the shortcomings of traditional aluminum-alloy gusset joints, i.e., the low bearing capacity caused by the lack of a shear connector that makes these joints unsuitable for an aluminum-alloy combined lattice-shell structure of a larger span, this paper proposes a novel joint with a high bearing capacity that has a cylindrical socket-and-spigot type shear connector at the center of the joint. Experimental research was carried out on the novel joint. The results show that the overall stiffness and shear resistance of the novel joint are greatly improved compared with those of a traditional gusset joint and that the out-of-plane bending capacity is more than $50 \%$ higher. The failure mode of the novel joint is mainly manifested by tension and shear block failure of the lower cover plate when the thickness of the gusset plate is small and torsional buckling failure of the connected aluminum-alloy beam. An elastoplastic finite-element parametric analysis based on multiple contacts shows that the bearing capacity of the proposed joint is related to the thickness of the connecting plates and the diameter and number of bolts. Based on the working mechanism of the novel joints, this paper offers a simplified calculation formula for the ultimate bearing capacity of the joint. The results of this paper can provide a theoretical basis for making and revising the design codes for this novel joint. Keywords: single-layer combined lattice shell, aluminum-alloy, novel joint, cylindrical socket-and-spigot type shear connector, bearing capacity test
\end{abstract}

Avtorji predlagajo nov način spajanja, da bi se izognili slabostim tradicionalnega trikotnega spoja iz Al zlitin oz. njihove majhne nosilnosti zaradi odsotnosti strižnega konektorja, ki naredi te spoje neprimerne za mrežno-lupinaste strukture z večjim razponom. Nov, predlagan način spajanja oz. vezave z veliko nosilnostjo, ima cilindrični strižni tip SaS (angl.: socket-and-spigot) konektorja v središču spoja. Avtorji so izvedli eksperimentalno raziskavo predlaganega spoja. Rezultati raziskave so pokazali, da je celokupna togost novega spoja in njegova odpornost proti strigu, precej izboljšana v primerjavi s tradicionalnim trikotnim spojem in, da je zunanja ravninska odpornost spoja pred upogibanjem boljša za več kot $50 \%$. Način porušitve novega spoja je v glavnem posledica nateznih obremenitev. Strig spodnje pokrivne plošče je blokiran pri majhni debelini trikotne plošče in tudi porušitev zaradi torzijskega upogibanja povezovalne gredi iz Al zlitine je preprečena. Elastoplastična parametrična analiza na osnovi metode končnih elementov mnogoterih kontaktov, je pokazala, da je nosilnost novega predlaganega spoja odvisna od debeline povezovalnih plošč ter premera in števila veznih vijakov. Na osnovi delovnega mehanizma novega spoja avtorji v tem članku podajajo enostavno enačbo za izračun nosilnosti predlaganega spoja. Rezultati, podani v tem članku, lahko predstavljajo teoretično osnovo za revizijo in izdelavo računalniške kode za dizajniranje predlagane vezi.

Ključne besede: enoslojna kombinirana mrežno lupinasta struktura, Al zlitina, nova vrsta spoja, cilindrični SaS-tip strižnega konektorja, test nosilnosti

\section{INTRODUCTION}

A wide range of joint forms are used in spatial grid structures, including the German Mero system, the American Unistrut system, the Canadian Triodetic system, and the Japanese NS system. ${ }^{1-2}$ An aluminum-alloy lattice-shell structure, due to its poor weldability, is generally mechanically connected. Common joint types include hub joints, Temcor joints (gusset joints), and cast aluminum joints. ${ }^{3-8}$ In the research on single-layer aluminum-alloy lattice-shell joints, G. G. Shi et al. ${ }^{9-10}$ of Tsinghua University conducted a series of studies on cast aluminum joints and found that the out-of-plane bending

*Corresponding author's e-mail

101000815@seu.edu.cn (Caiqi Zhao) stiffness is higher than the in-plane bending stiffness; they also identified the most unfavorable position of the joint. Y. Q. Wang et al. ${ }^{11}$ performed a nonlinear finiteelement analysis on aluminum-alloy gusset joints based on experimental data. The results showed that the force acting on the cover plate is transmitted to the aluminumalloy beam through the bolt group and that the specimen is first formed with a plastic zone at the last row of bolt holes of the flange and at the bottom of the web.

J. H. Qian et al. ${ }^{12}$ showed that in the design of Temcor joints, the diameter and thickness of the circular cover plate and the specification and quantity of the connection bolts are all key parameters. In the literature ${ }^{13-16}$ authors have analyzed the factors affecting the stiffness of the circular aluminum-alloy cover plate-gusset joint, 
but did not consider the influence of the bolts. X. N. Guo et al. ${ }^{17-19}$ studied the bending mechanism of gusset joints, obtained the bending-moment rotation-angle curve via experiments and used parameter analyses to obtain the pattern of influence of factors such as the thickness of the gusset plate, the height of the aluminum-alloy beam and the number of bolts on the initial stiffness.

These research studies were generally carried out on existing traditional aluminum-alloy gusset joints. However, the web of the aluminum-alloy beam in a gusset joint is discontinuous in the joint region due to the absence of a shear connector in the central region of the joint; thus, the joint is supported only by the upper and lower flanges of the connected beam. This feature provides a limited shear bearing capacity, and it cannot meet the bearing-capacity demands of a larger span lattice-shell structure. This paper proposes a new type of aluminum-alloy joint with a built-in core shear connector. Studies have shown that this joint has a higher overall stiffness and load-bearing capacity than traditional gusset joints. It is applicable not only to general single-layer aluminum-alloy lattice-shell structures but also to aluminum-alloy composite lattice-shell structures that incorporate aluminum-alloy honeycomb panels. ${ }^{20-24}$ By means of a theoretical analysis and experimental research, this paper further explores the force performance, force transmission mechanism and failure mechanism of the novel joint and proposes a simplified formula to provide a theoretical basis for the design procedure of these joints in the future.

\section{EXPERIMENTAL PART}

\subsection{Design and production of test specimen}

To explore the stress characteristics, bearing capacity and failure mechanism of the novel joint, six aluminumalloy joints are designed. Three of them are novel joints (numbered JD1, JD3 and JD5), and the other three are traditional joints (numbered JD2, JD4 and JD6). The plane of each specimen is a regular hexagon with a diameter of $2000 \mathrm{~mm}$ (Figure 1a). Each joint is connected with $6 \mathrm{H}$-shaped aluminum-alloy beams (the cross-sectional dimensions are $110 \mathrm{~mm} \times 60 \mathrm{~mm} \times 5 \mathrm{~mm} \times$ $5 \mathrm{~mm}$ ), and the other end of the beam is supported by 6 steel columns (Figures $\mathbf{1 b}$ and $\mathbf{1 c}$ ). The novel joint consists of two upper and lower circular cover plates and a cylindrical socket-and-spigot type shear connector located between them (Figure 1d). The circular cover plates have a diameter of $280 \mathrm{~mm}$ and three thicknesses of $6 \mathrm{~mm}$ (JD1 and JD2), $4 \mathrm{~mm}$ (JD3 and JD4) and $3 \mathrm{~mm}$ (JD5 and JD6). Each of the cover plates is drilled with 8 holes at a $60^{\circ}$ angle (Figures 1e and 1f), and 8 M6 stainless steel bolts are used to connect the flanges of the aluminum-alloy beam ends. The diameter of the cylindrical socket-and-spigot type shear connector is 70 $\mathrm{mm}$, and the height is $100 \mathrm{~mm}$. Six "T-shaped" grooves are machined using a numerical control machine tool along a $60^{\circ}$ angle (Figures $\mathbf{1 g}$ and $\mathbf{1 h}$ ). After inserting six "T-shaped" shear connection plates into the grooves, the M6 bolts are used to connect the plates to the webs of the beam ends (Figures $\mathbf{1 i}$ and $\mathbf{1 j}$ ). The conventional joint is not provided with a cylindrical shear connector;
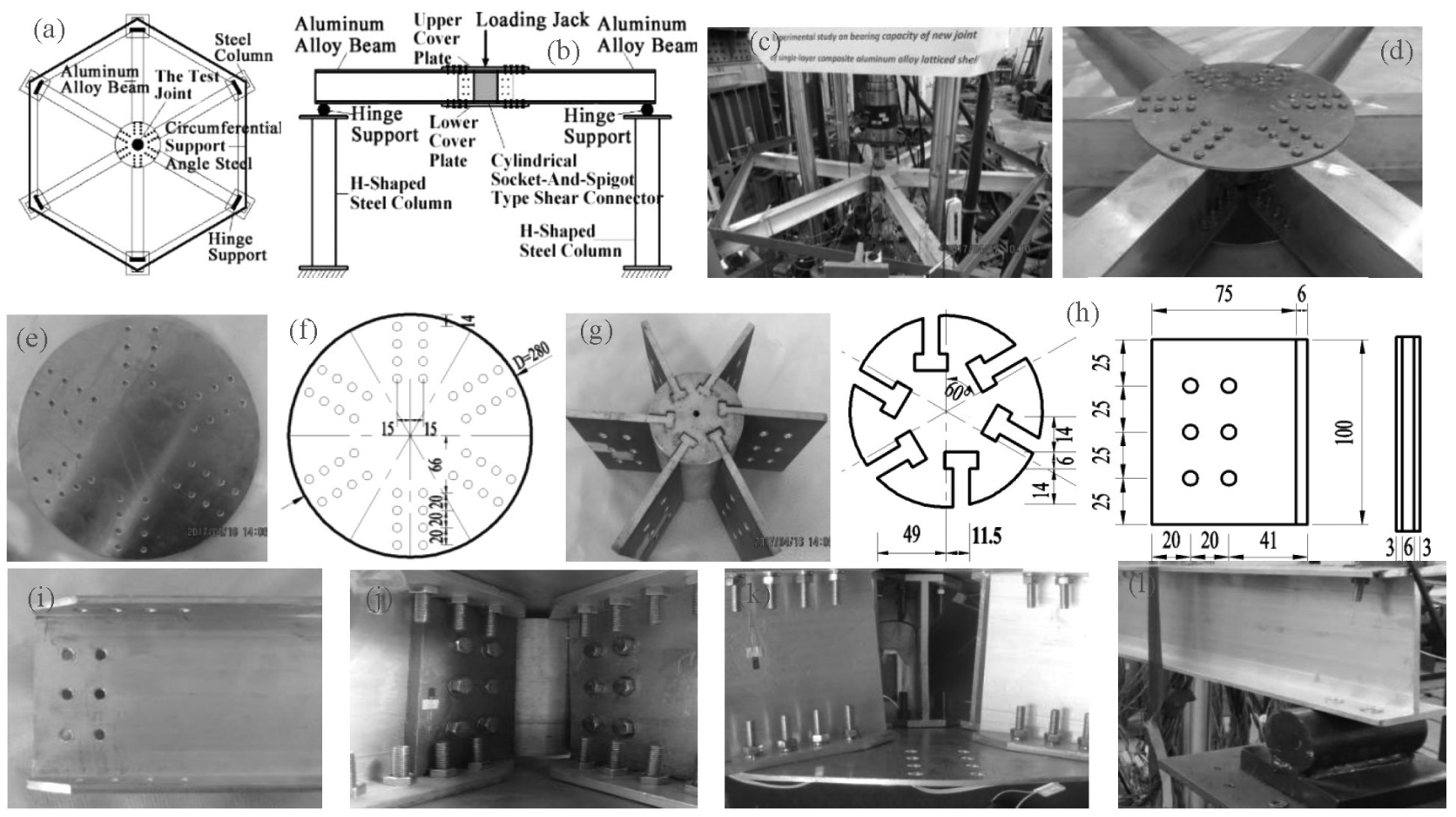

Figure 1: Test model overview: a) top view, b) side view, c) the loading site, d) the test joint, e) and f) the cover plate, g) and h) the socket-and-spigot type shear connector, i) an aluminum-alloy beam, j) a novel joint, $\mathrm{k}$ ) a traditional joint, and 1 ) support at the end of the beam 
only the upper and lower circular cover plates are connected to the flanges of the beam ends, and there are no connections between the webs at the ends of the beams (Figure 1k). The test joints are largely made of 6061-T6 aluminum alloy, except for the connection bolts, which are made of 304 stainless steel.

\subsection{Loading and testing methods}

The displacement measuring points of the test joint are arranged at the mid-span loading and the locations of the six supports. The strain gauges and the strain rosette are arranged in locations with a large stress, i.e., on the upper and lower cover plates of the joint, on the flanges and webs of the aluminum-alloy beams, and close to the vicinity of the connection bolts (Figure 2).

The test uses the MTS autoload control system to apply a centralized load at the center of the joint. Loading is applied according to a displacement sensor at a speed of $0.02 \mathrm{~mm} / \mathrm{s}$. To prevent the six steel columns from being turned by the eccentric pressure during the loading process, a support system consisting of lateral inclined supports and horizontal coupling beams is arranged between the steel columns. A rigid circular block is placed at the loading point of the upper cover to prevent the loading head from hitting the connection bolts on the cover plate and affecting their normal force transmission.

\section{RESULTS AND DISCUSSION}

\subsection{Failure mode of test joints}

\subsubsection{Failure mode of novel joints}

Due to space limitations, only the damage process of JD1 is provided here; those of the other two cases (JD3 and JD5) are similar. The loading no longer increases and begins to decrease when the load reaches $71 \mathrm{kN}$, and it stops when the load decreases to $60 \mathrm{kN}$. The bending deformation of the aluminum-alloy beams is obvious. The deformation of several bolt holes on the flange of the aluminum-alloy beams away from the center of the joint is severe, and some individual nuts are embedded in the holes. If the loading continues, the aluminum-alloy beam will be broken. Due to the large thicknesses of the upper and lower cover plates, only slight bending deformations occurred. At the lower end of the cylindrical socket-and-spigot-type shear connector, the tensile deformation is obvious; however, there are no apparent cracks, and the shear connection plates show no obvious deformation. The bolts connecting the upper and lower cover plates and the flanges of the aluminum-alloy beams show compression and shear deformation and tensile and shear deformation, and the bolts between the shear connection plates and the aluminum-alloy beam webs also underwent compression and shear deformation (Figure 3).

\subsubsection{Failure mode of traditional joints}

Only the damage process of JD6 is provided here; those of the other two cases (JD2 and JD4) are similar.

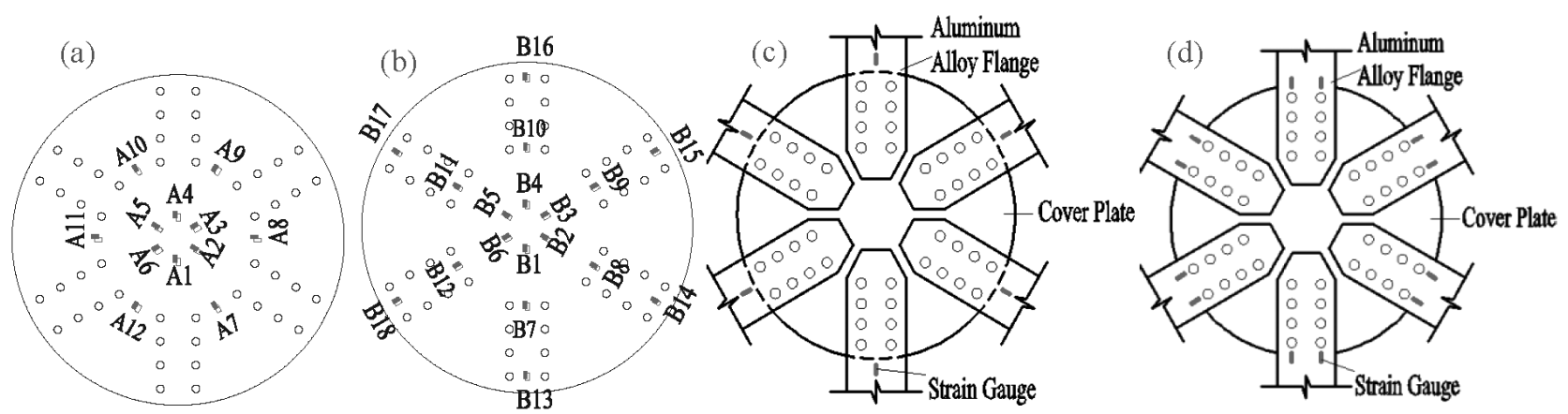

Figure 2: Strain measurement point layout: a) inner surface strain measuring point of the upper cover, b) outer surface strain measuring point of the lower cover, c) inner surface strain measuring point of the aluminum-alloy beam flange, and d) outer surface strain measuring point of the aluminum-alloy beam flange
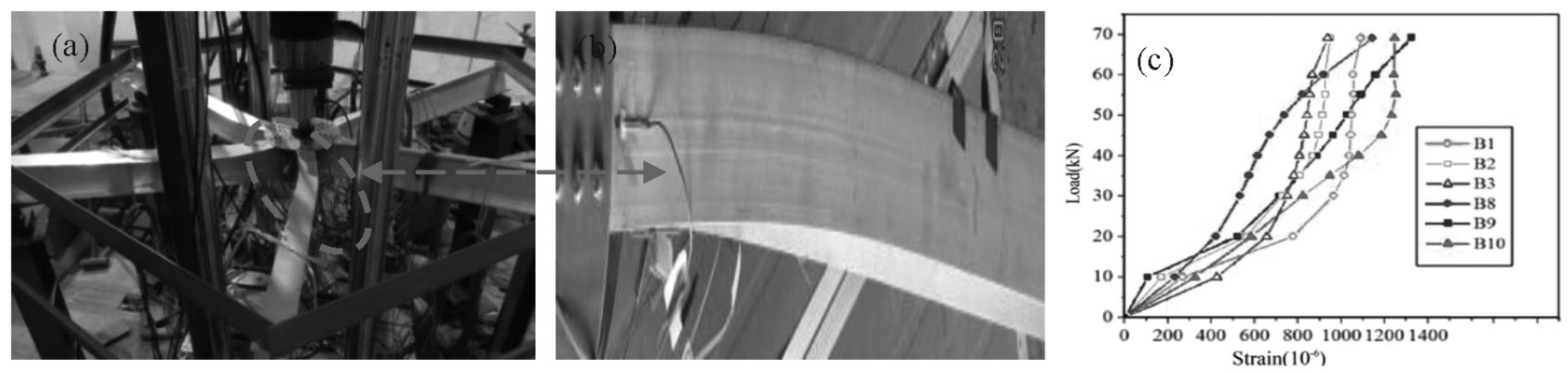

Figure 3: Novel joint (JD1) failure mode: a) deformation after loading, b) torsional deformation of aluminum-alloy beams, and c) load-strain curves 
Since JD6 is a traditional joint connected only by the upper and lower cover plates, its bearing capacity is significantly lower than that of the novel joint, and its damage form is also very different. A rustling sound was heard when the loading reached $41 \mathrm{kN}$; a large metal breaking sound was produced when the joint was loaded to $52 \mathrm{kN}$, and the load value plummeted to $13 \mathrm{kN}$, at which point the bolt holes of the lower cover were torn. Significantly different from the failure mode of the novel joint, the upper and lower cover plates of the traditional joints were damaged by block shearing along the direction of the bolt-hole connection. The bolts connecting the upper and lower cover plates and the flanges of the aluminum-alloy beams produced compression and shear deformation (Figure 4).

\subsection{Test result analysis}

1) A comparison of the novel joint and the traditional gusset joint shows that the shearing capacity and the out-of-plane bending capacity are significantly improved due to the setting of the cylindrical socket-and-spigottype shear connector in the central area of the novel joint, with an average increase of greater than $50 \%$.

2) Three different aluminum-alloy joint experimental tests show that the failure mode of the traditional gusset joint is either the tension and shear block failure of the lower cover plate or the bending damage of the aluminum-alloy beam. The failure mode of the novel joint is mainly represented by the torsional buckling failure of the connected aluminum-alloy beam. The block shearing damage of the lower cover plate occurs only when the thickness of the gusset plate is small. In contrast to the traditional joint, the thicknesses of the upper and lower cover plates of the novel joint have little effect on its bearing capacity. This is mainly because the shear connectors in this type of joint share a large part of the load-bearing capacity.

\subsection{Elastoplastic finite-element analysis of novel joints}

\subsubsection{Analysis method}

The constitutive relationship of the component materials in the test joint is shown in Figure 5. To improve the accuracy and convergence speed of the finite-element analysis results, when the finite-element model is constructed, a fine meshing is used for the parts with holes and the parts where stress concentration can easily occur ${ }^{25-29}$ (Figure 6). Additionally, to fully consider the contact between the upper and lower covers and the aluminum-alloy beams and the contact between the stainless-steel bolts and the bolt holes, face-to-face contact unit connections are used. ${ }^{30-35}$ According to the loading method and the bearing condition in the test, the boundary constraint is set at the distal end of the aluminum-alloy beams, and the vertical displacement load is applied at the center position of the joint.

\subsubsection{Analysis results}

It can be seen from the stress contour diagrams in Figures 7a to 7c that the stresses on the upper and lower cover plates of JD1 and the bolt holes are the greatest (260MPa), and the stress near the loading point in the
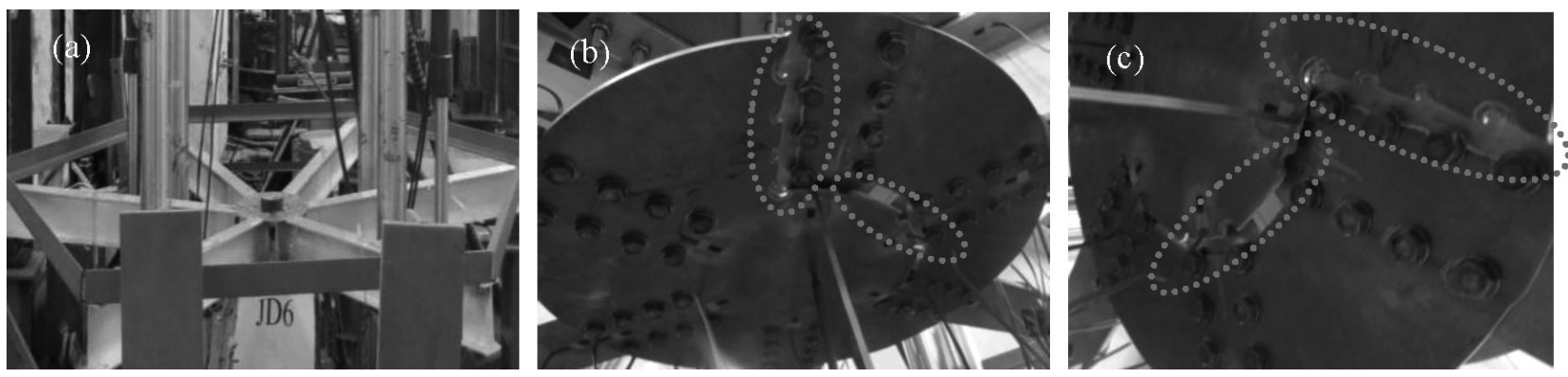

Figure 4: Traditional joint (JD6) failure mode: a) overall deformation, b) and c) shear failure of the lower cover plate
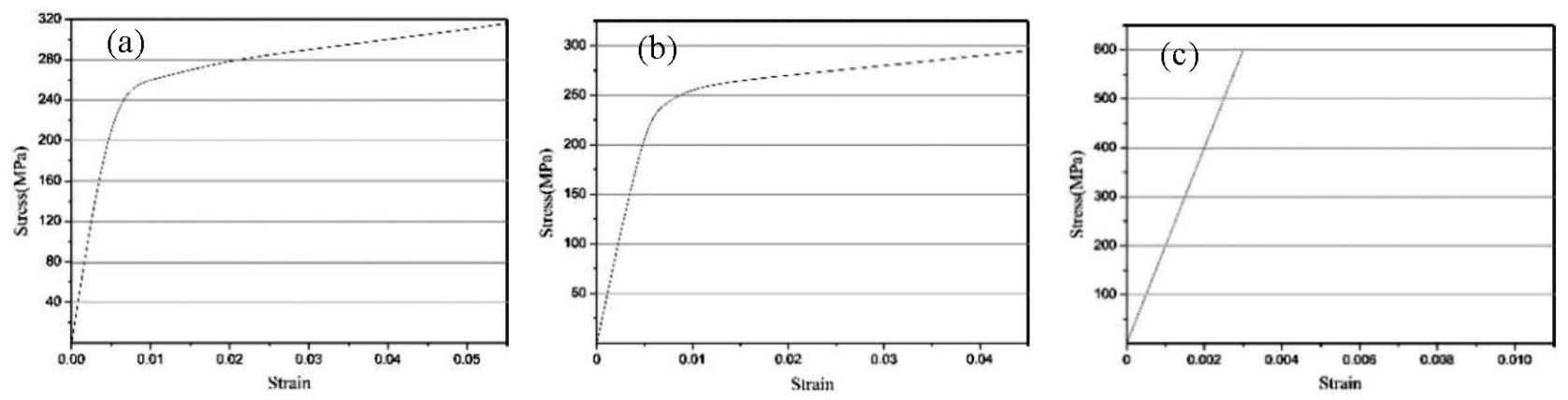

Figure 5: Constitutive relationship curves of the joint materials: a) aluminum-alloy beam, b) aluminum-alloy cover plate and connector and c) stainless-steel bolt ${ }^{35}$ 

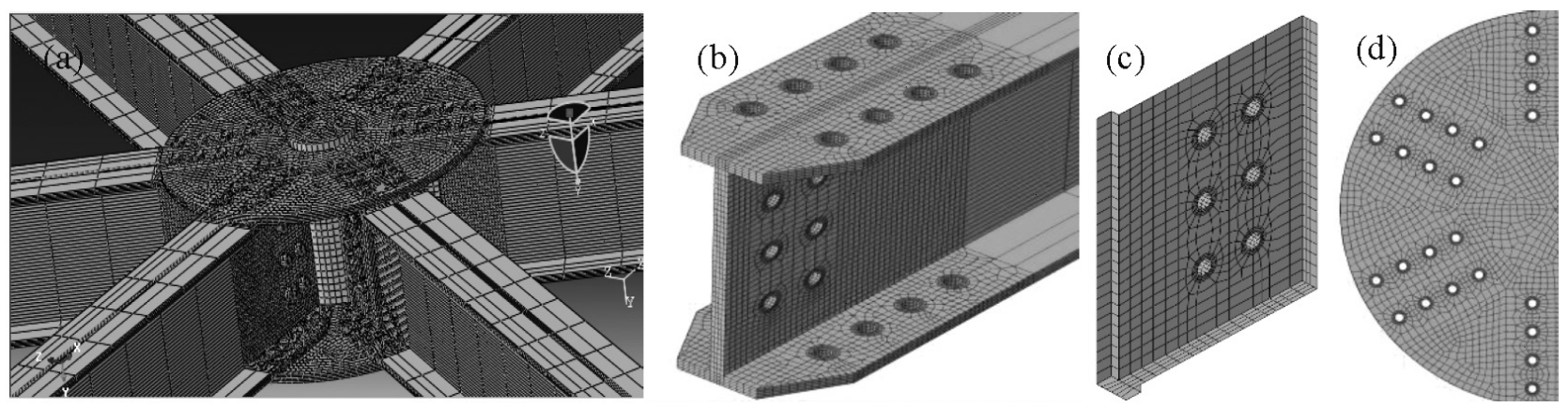

Figure 6: Finite-element model of the joint: a) the overall structure, b) an aluminum-alloy beam, c) a shear connection plate and d) upper and lower cover plates

central area of the upper cover plate is also large $(238 \mathrm{MPa})$. It can be seen from the different stress distributions at the bolt holes of the upper and lower cover plates that the upper cover-plate bolt holes are more compressed at the near-center ends. The bolt holes of the lower cover plate are also subjected to compression at the telecentric end, as shown in a partially enlarged view.

Figure 7d shows a von Mises stress-contour diagram of an aluminum-alloy beam after loading. The upperflange stress developed in the aluminum-alloy beam is asymmetrical, and thus, the aluminum-alloy beam is twisted, which is consistent with the phenomenon observed in the test. A plastic zone is formed near the bolt holes of the lower flange of the beam away from the cover plate; it is presumed that the damage location should be located here, which is also consistent with the phenomenon observed in the test.

Figure 7e shows that the stress is not large, except where the shear connector is in contact with the inner surface of the flange of the aluminum-alloy beam, where it reaches the ultimate stress. This result shows that the shear connector has sufficient stress reserve and conforms to the design concept of a "strong joint-weak member".

Figure 7f shows that the theoretical load-displacement curves of the novel joint agree well with the measured experimental curves. The average error between them is $3.6 \%$.

\subsection{Influential factors and simplified formula for novel joint's bearing capacity}

\subsubsection{Influential factors of novel joint's bearing capacity}

Studies $^{17-19}$ have shown that the bearing capacity of a traditional joint is related mainly to the thicknesses of the upper and lower cover plates and the distribution of the bolts. The novel joint is based on the traditional joint with a shear connector added to the core area; thus, its bearing capacity is related to the installed shear connection plates and their connection bolts. To examine the influence of the thickness of the shear connection plate and the diameter and quantity of the connection bolts on the bearing capacity of the novel joint under the circumstance where the thicknesses of the upper and lower cover plates are constant, this study selected 5
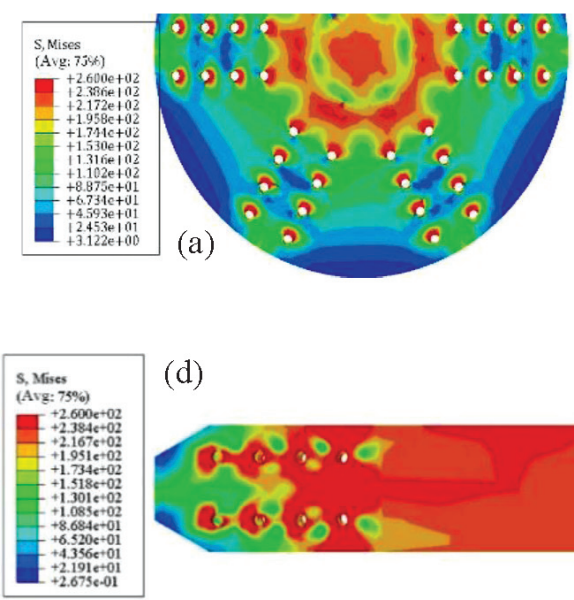

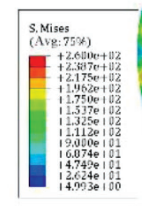

(b)
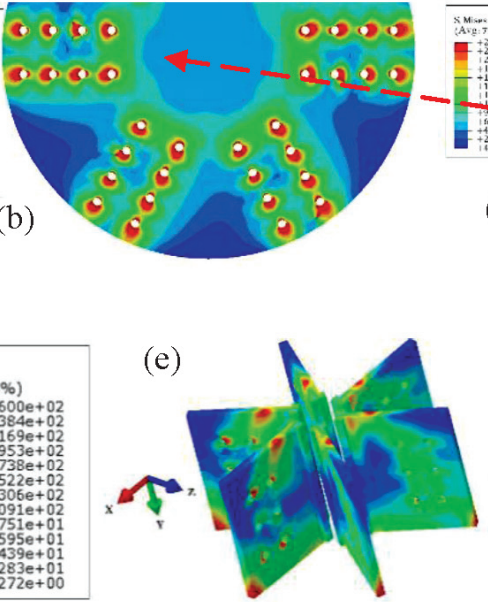
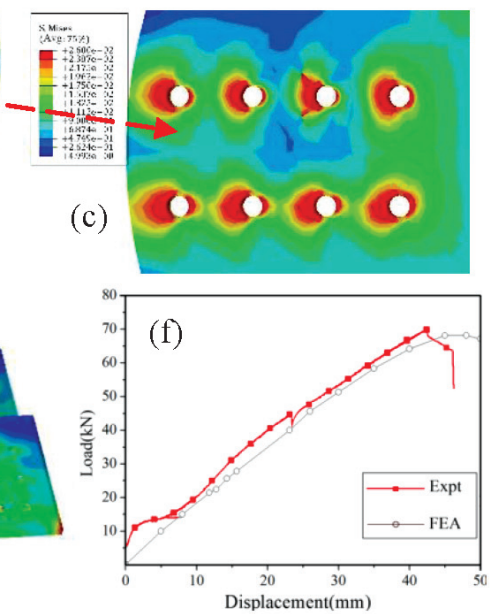

Figure 7: Stress and displacement conditions of JD1: a) the inner surface of the upper cover plate, b) the outer surface of the lower cover plate, c) the vicinity of the bolt holes of the lower cover plate, d) stress-contour diagram of beam, e) stress-contour diagram of the shear connector and f) load-displacement curves 

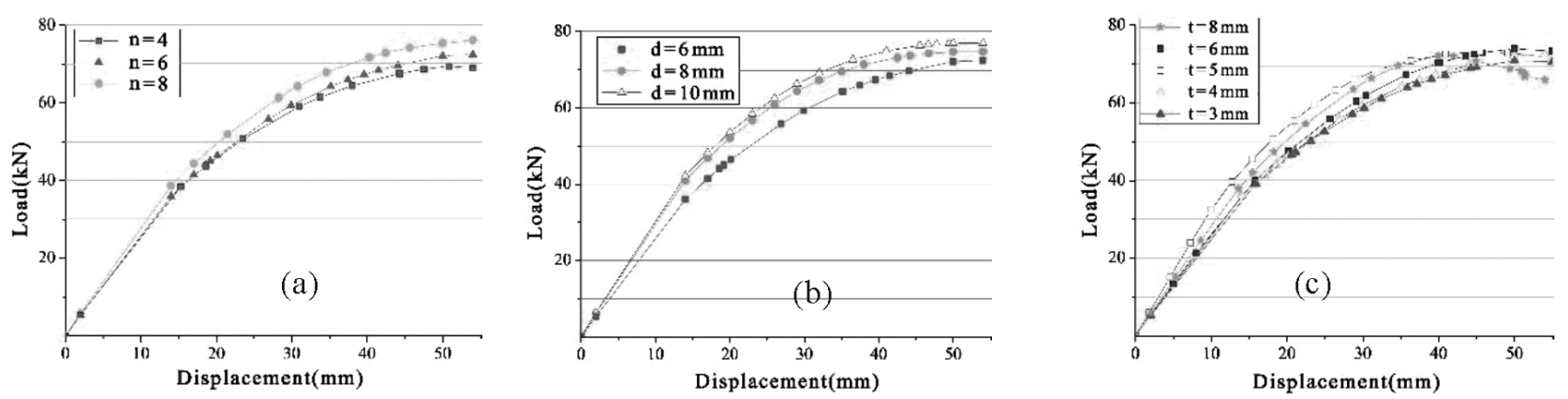

Figure 8: Joint bearing capacity parametric analysis result: a) $t=4 \mathrm{~mm}, d=6 \mathrm{~mm}$, b) $t=4 \mathrm{~mm}, n=6$, and c) $n=6, d=6 \mathrm{~mm}$

shear connection plates of different thicknesses $(t=$ $3 \mathrm{~mm}, 4 \mathrm{~mm}, 5 \mathrm{~mm}, 6 \mathrm{~mm}, 8 \mathrm{~mm}$ ) and connection bolts of 3 different diameters $(d=6 \mathrm{~mm}, 8 \mathrm{~mm}, 10 \mathrm{~mm})$ and quantities $(n=4,6,8)$; thus, a total of 45 joint models were used to carry out the finite-element parametric analysis.

Figure 8 shows part of the results for the analysis of the joint's bearing-capacity parameter when shear connection plates of different thicknesses and bolts of different diameters and quantities were used when the joint cover plates were $4 \mathrm{~mm}$ thick. Figure 8a indicates that in the case where the thicknesses of the upper and lower cover plates and the bolt diameter are unchanged, the bearing capacity of the joint can be improved by increasing the number of bolts on the connection plates; the average increase in the bearing capacity is approximately $6 \%$ after the bolt number is increased. However, taking on-site construction factors into consideration, the workload of the on-site installation will expand if too many bolts are involved. Figure $\mathbf{8 b}$ reveals that in the circumstance where the thickness of the connection plates and the number of bolts is unchanged, the bearing capacity of the joint increases as the bolt diameter increases, yet its increment is not large.

Figure 8c illustrates that under the condition where the diameter and number of connection bolts are fixed, the bearing capacity of the joint can be improved by increasing the thickness of the shear connection plates. When the thickness of the shear connection plates reaches the beam web thickness of $5 \mathrm{~mm}$, the slope of the load-displacement curve of the joint is greater than that of the other curves. Therefore, in the future design of such joints, it is recommended that the thickness of the connection plates remains consistent with the beam web thickness.

\subsubsection{Simplified formula for novel joint's bearing capacity}

This study indicates that the joint's failure mode is determined as follows: when the thickness of the upper and lower cover plates is less than that of the aluminum-alloy beam flange, tension and shear block failure of the cover plates will occur. When the thickness of the cover plates is greater than that of the beam flange, fracture failure of the aluminum-alloy beams or failure of the connection bolts will occur.

\subsubsection{Out-of-plane bearing capacity of the joint at the failure of the cover plates}

According to the experiment, when loading is applied to the ultimate load, fracture-zone failure occurs on the cover plates. The tensile cover plates of the joint can present three types of shearing failure under the action of the bolt group: single-fan-shaped area failure, doublefan-shaped area failure, and tri-fan-shaped area failure, as shown in Figure 9.

1) Single-fan-shaped area tensile and shear failure

$$
V_{\mathrm{u} 1}=k t f_{\mathrm{u}} \sum_{i=1}^{3} \eta_{i} l_{i} \geq N_{1}
$$

In Equation (1), $V_{\mathrm{u} 1}$ is the bearing capacity of the single-fan-shaped area tensile and shear failure, is the thickness of the cover plate, $f_{\mathrm{u}}$ is the ultimate tensile strength of the material, $\mathrm{li}$ is the net length of the $i^{\text {th }}$ (a)

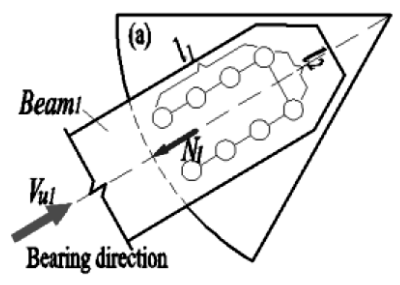

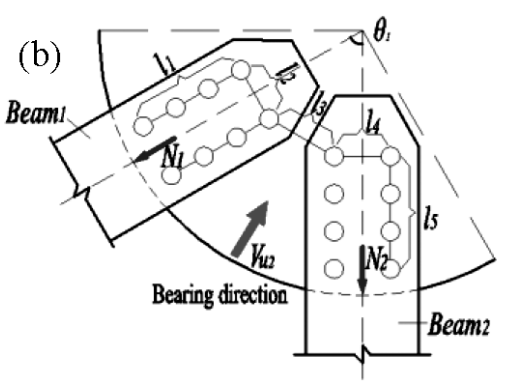

(c)

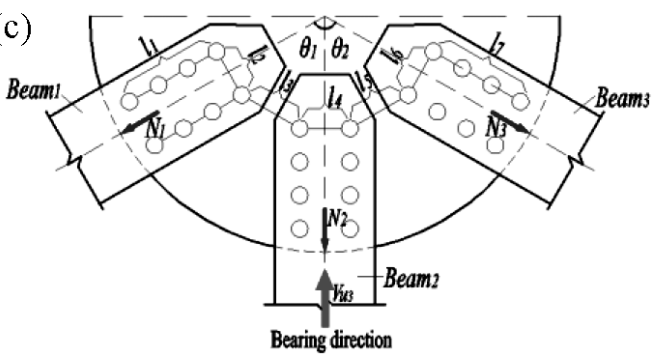

Figure 9: Tensile and shear failures of the lower cover plate: a) single-fan-shaped area failure, b) double-fan-shaped area failure, and c) tri-fanshaped area failure 
failure side, $l_{1} \sim l_{3}$ are the failure-side net lengths of the single-fan-shaped area tensile and shear failure, and $N_{1}$ is the tensile force of aluminum-alloy beam $L_{1}$. $\eta_{i}$ is the equivalent failure intensity coefficient of the material at the $i^{\text {th }}$ failure side, which is the normal stress and the shearing stress on the failure side. Under the circumstance where von Mises yielding conditions are met, $\eta_{\mathrm{i}}$ is the ratio of the maximum value of the projection of the resultant force in the failure-bearing direction and the ultimate tensile strength of the material with respect to the single-fan-shaped area tensile and shear failure, $\eta_{1}=$ $\eta_{3}=0.58$ and $\eta_{2}=1 . k$ is the bearing-capacity reduction factor caused by the partial bending of the cover plate.

2) Double-fan-shaped area tensile and shear failure

$$
V_{\mathrm{u} 2}=k t f_{\mathrm{u}} \sum_{i=1}^{5} \eta_{i} l_{i} \geq N_{1}+N_{2}
$$

$V_{\mathrm{u} 2}$ is the bearing capacity of the double-fan-shaped area tensile and shear failure, and $N_{1}$ and $N_{2}$ are the tensile forces of aluminum-alloy beams $L_{1}$ and $L_{2}$, respectively. $l_{1} \sim l_{5}$ are the failure-side net lengths of the doublefan-shaped area tensile and shear failure. $\eta_{2}$ depends on the angle $\theta_{1}$ between two adjacent aluminum-alloy beams of the double-fan-shaped area.

Tri-fan-shaped area tensile and shear failure

$$
V_{\mathrm{u} 3}=k t f_{\mathrm{u}} \sum_{i=1}^{7} \eta_{i} l_{i} \geq N_{1}+N_{2}+N_{3}
$$

In Equation (3), $V_{\mathrm{u} 3}$ is the bearing capacity of the tri-fan-shaped area tensile and shear failure, $l_{1} \sim l_{7}$ are the failure-side net lengths of the tri-fan-shaped area tensile and shear failure, and $N_{1}, N_{2}$ and $N_{3}$ are the tensile forces of aluminum-alloy beams $L_{1}, L_{2}$ and $L_{3}$, respectively. The value of $\eta_{\mathrm{i}}$ depends on the angle between the adjacent aluminum-alloy beams corresponding to the tri-fanshaped area. $i=1,2,3$ relates to $\theta_{1}$, and $i=4,5,6$ relates to $\theta_{2}$.

\subsubsection{When the aluminum alloy beam fractures}

When the thickness of the cover plate is greater than that of the aluminum-alloy beam flange and the bearing capacity of the bolts is sufficiently large, fracture failure of the aluminum-alloy beams will occur. The fracture zone is distributed along the outermost region of the cover plate center where the bolt holes are located. Considering that hole weakening is present at the web connecting to the shear connector, the formula is expressed as follows:

$$
\begin{gathered}
\sigma=\frac{M}{w_{1}}>[\sigma] \\
W_{1}=(b-s d) \cdot t_{\mathrm{f}} \cdot\left(h-t_{\mathrm{f}}\right)+\frac{t_{\mathrm{w}} \cdot\left(h-2 t_{\mathrm{f}}-n d\right)^{2}}{6}
\end{gathered}
$$

The bending moment generated by the friction between the bolt and aluminum-alloy beam was not considered in Equations (4) and (5), where $W_{1}$ is the bending section modulus of the aluminum-alloy beam cross-

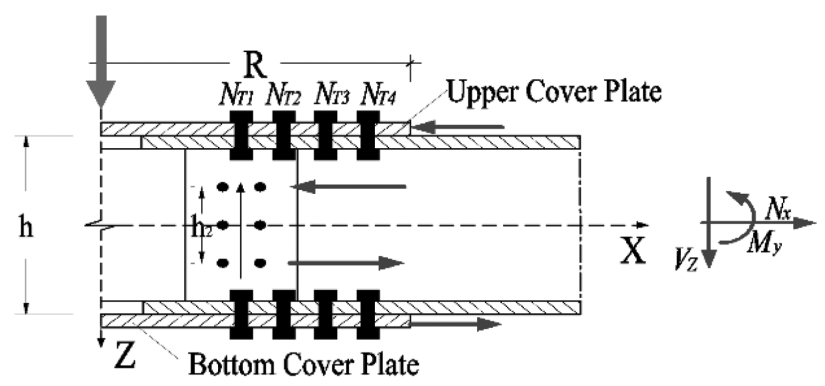

Figure 10: Diagram of novel joint's bearing-capacity calculation

section, $n$ is the number of bolt rows on the web, and $[\sigma]$ is the allowable stress of the material.

\subsubsection{When the bolts fail}

Assuming that the requirements for the bearing capacity of the cover plates and aluminum-alloy beams are met, the bearing capacity of the joint is controlled mainly by the bolt's strength. Due to the introduction of a shear connector in the novel joint, the out-of-plane bending moment is carried collectively by the bolts between the upper and lower cover plates and aluminumalloy beam flanges, together with the bolts between the webs and the shear connector. Set $\alpha=V_{\mathrm{y}} \cdot R / M_{\mathrm{y}}, \beta=$ $N_{\mathrm{x}} \cdot h / M_{y}$, where $R$ is the radius of the cover plate, and $h$ is the height of the aluminum-alloy beam, as shown in Figure 10. The resulting equation is as follows:

$$
\begin{gathered}
M_{\text {total }}=M_{y}+V_{y} \frac{R}{2}+N_{x} \frac{h}{2} \\
M_{\text {total }}=M_{y} \cdot\left(1 \pm \frac{\alpha}{2} \pm \frac{\beta}{2}\right)
\end{gathered}
$$

In Equation (6), $M_{\text {total }}$ is the total out-of-plane bending moment carried by the joint, $M_{\mathrm{u}}$ is the out-of-plane bending-resistance bearing capacity of the joint, $M_{\mathrm{y}}$ is the out-of-plane bending moment, $V_{\mathrm{y}}$ is the shear force in the direction of the y-axis, $N_{\mathrm{x}}$ is the axial force in the $\mathrm{x}$ direction, $R$ is the radius of the cover plate, $\mathrm{h}$ is the height of an aluminum-alloy beam, $n_{1}$ is the number of bolts for each fan-shaped area on the joint plate, $N_{\mathrm{T} 1}$ is the shear bearing capacity of the bolt on the cover plate, $n_{2}$ is the number of bolts on the shear connector, $N_{\mathrm{T} 1}$ is the shear bearing capacity of a bolt on the shear connection plates, and $h_{2}$ is the spacing of the bolt centers on the shear connector, as shown in Figure 10. The formulas are as follows:

or

$$
\begin{gathered}
M_{\mathrm{u}}=n_{1} \cdot N_{\mathrm{T} 1} \cdot h+n_{2} \cdot N_{\mathrm{T} 2} \cdot h_{2} \\
M_{\mathrm{u}}=n_{1} \cdot N_{\mathrm{T} 1} \cdot h \cdot(1+\gamma) \\
\gamma=\frac{n_{2} \cdot N_{\mathrm{T} 2} \cdot h_{2}}{n_{1} \cdot N_{\mathrm{T} 1} \cdot h_{1}}
\end{gathered}
$$

By substituting relevant parameters of the test joints into the above formulas, the mean error between the theoretical calculated bearing capacity and the measured 
bearing capacity is within $5 \%$, indicating that the simplified formula has good computational accuracy.

\section{CONCLUSIONS}

To resolve the shortcomings of traditional gusset joints, which are widely used in current single-layer aluminum-alloy lattice-shell structures, a novel joint of a cylindrical socket-and-spigot-type shear connector was proposed in this paper for the first time. An experimental study and an elastoplastic finite-element analysis were conducted to provide an initial examination of the stress characteristics and failure mechanism of this joint. The following main conclusions were obtained:

1) By means of experiments performed on the novel joint and a traditional gusset joint, it is revealed that because a cylindrical socket-and-spigot-type shear connector is installed in the central area of the novel joint, its overall stiffness and shearing resistance are significantly higher than those of the traditional joint, and the average increment of its out-of-plane anti-bending bearing capacity is above $50 \%$.

2) Three different sets of aluminum-alloy joint tests indicated that the failure modes of traditional gusset joints are tensile and shear block failure of the lower cover plate or bending failure of the aluminum-alloy beams. The main failure mode of the novel joint is torsional buckling failure of the connected aluminumalloy beams. The tensile and shear block failure of the lower cover plate occurs only when the thickness of the joint plate is small. The bearing capacity is not affected greatly by the thicknesses of the upper and lower cover plates.

3) The multiple-element contact-based elastoplastic finite-element parametric analysis indicates that the theoretical load-displacement curves of the novel joint agree well with the measured experimental curves. Although the bearing capacity of the joint increases with the thickness of the connection plates, the increase is very limited after the thickness exceeds that of the web. Therefore, it is recommended that the thickness of the connection plates be the same as that of the web.

4) A simplified formula for the ultimate bearing capacity is offered based on the working mechanism of the novel joint, providing the future structural design of this novel joint with a theoretical basis.

\section{Acknowledgments}

This study was supported by the Natural Science Foundation of China under Grant No. 51578136.

\section{REFERENCES}

${ }^{1}$ L. P. Yang, S. Wei, Q. L. Zhang, Research status and key issues of aluminum alloy spatial lattice structure, Journal of Building Structure, $34 \quad$ (2013) 2, 1-19, doi:10.1108/s0735$004 \times 20140000027001$
${ }^{2}$ R. Bradshaw, D. Campbell, M. Gargary, Special structures: past, present, and future, Journal of Structural Engineering, 128 (2002) 6, 691-709, doi:10.1108/s0735-004x20140000027001

${ }^{3}$ EN 1999-1-1:2000: Design of aluminium alloy structures, General rules for buildings, Europe

${ }^{4}$ AS/NZS 1664.1: 1999, Aluminum structures, Part 1: Limit state design, Australia and New Zealand

${ }^{5}$ AS/NZS 1664.1: 1999, Aluminum structures, Part 1: Limit state design, Australia and New Zealand

${ }^{6}$ K. Sugizaki, S. Kohmura, Y. Hangai, Experimental study on structural behaviour of an aluminum single-layer lattice shell, Transactions of AIJ, 61 (1996) 480, 113-122, doi:10.3130/ aijs.61.113_1

${ }^{7}$ Y. Hiyama, H. Takashima, T. Iijima, Experiments and analyses of unit single layered reticular domes using aluminum ball joints for the connections, Transactions of AIJ, 64 (1999) 518, 3-40, doi:10.3130/ aijs.64.33_1

${ }^{8} \mathrm{~S}$. Xu, Experimental study on the temco node and analysis of the performance of aluminum alloy single-layer reticulated shell structure, Diss, Tianjin University, 2015

${ }^{9}$ G. Shi, C. Luo, Y. Q. Wang, Experimental study on mechanical behavior of new cast aluminum joints in aluminum alloy reticulated shell structures, Journal of Building Structure, 33 (2012) 3, 70-79, doi:10.14006/j.jzjgxb.2012.03.010

${ }^{10}$ G. Shi, C. Luo, Y. Q. Wang, Research on design method of new cast aluminum joint bearing capacity in aluminum alloy reticulated shell structure, Architectural Science, 16 (2000) 5, 78-84, doi:10.13849/ j.issn.1006-6578.2012.01.013

${ }^{11}$ Y. Q. Wang, X. C. Liu, Y. J. Shi, J. Yin, Finite element analysis of mechanical behavior of disc joints in aluminum alloy reticulated shells, Journal of Tianjin University, Natural Science and Engineering Technology Edition, 48 (2015) 7, 2-5

${ }^{12}$ J. H. Qian, P. F. Zhao, C. X. Hao, Research on the structure of long span aluminum alloy dome reticulated shell, Architecture Science, 16, (2000) 5, 7-12, doi:10.13614/j.cnki.11-1962/tu.2000.05.002

${ }^{13} \mathrm{~J}$. Zhang, The stiffness of reticulated joints and its effect on overall stability, China, Shanghai Jiaotong University, 2003

${ }^{14}$ L. W. Wang, W. Yang, Y. Feng, Design of aluminum alloy singlelayer reticulated shell structure for swimming fencing hall of China modern Pentathlon Center, Building Construction, 40 (2010) 9 , 73-76, doi:10.19701/j.jzjg.2010.09.018

${ }^{15}$ J. C. Zhao, H. M. Xu, Stress analysis of single-layer reticulated shells in Shanghai Science and Technology museum, Industrial Construction., 10, 31 (2001) 7-9, doi:10.13204/j.gyjz2001.10.003

${ }^{16} \mathrm{~S}$. Lai, Stress analysis of single-layer aluminum Reticulated shell joints of $60 \mathrm{~m}$ diameter Tank top, Petrochemical Equipment Technology, 28 (2007) 4, 11-15

${ }^{17}$ X. N. Guo, Z. Xiong, Y. F. Luo, W. Xu, Experimental study on bearing capacity of aluminum alloy plate joints, Journal of Tongji University, Natural Science Edition, 42 (2014) 7, 1024-1030

${ }^{18}$ X. N. Guo, Z. Xiong, Y. F. Luo, Initial stiffness of aluminum alloy plate joints, Journal of Tongji University, Natural Science Edition, 42 (2014) 8, 1162-1165

${ }^{19}$ X. N. Guo, L. Q. Qiu, Experimental study on flexural bearing capacity of aluminum alloy plate joints, Journal of Hunan University, Natural Science, 41 (2014) 47-53

${ }^{20}$ C. Q. Zhao, J. Ma, Assembled honeycombed sheet light empty stomach building and roof structure system, Patent, Application No. 200810100745.X, Publication No. CN101270595A

${ }^{21}$ C. Q. Zhao, S. Du, J. Chen, Mechanical relationships between the fiber-lamination methods and the structural functions of oryctes rhinoceros horns, Materials and technology, 53 (2019) 1, 17-23, doi:10.17222/mit.2018.119

${ }^{22}$ C. Q. Zhao, W. D. Zheng, J. Ma, Y. J. Zhao, Lateral compressive buckling performance of aluminum honeycomb panels for long-span hollow core roofs, Materials, 9 (2016) 444, doi:10.3390/ma9060444 


\section{ZHAO et al.: MECHANICAL PROPERTIES OF A NOVEL JOINT OF A SINGLE-LAYER ALUMINUM-ALLOY ...}

${ }^{23}$ C. Q. Zhao, W. D. Zheng, J. Ma, Y. J. Zhao, Shear strength of different bolt connectors on large span aluminium alloy honeycomb sandwich structure., Appl. Sci., 7 (2017) 450, doi:10.3390/ app7050450

${ }^{24}$ C. Q. Zhao, J. Ma, Y. J. Zhao, The stability of new single-layer combined lattice shell based on aluminum alloy honeycomb panels., Appl. Sci., 7 (2017) 1150, doi:10.3390/app7111150

${ }^{25}$ T. S. Kim, H. Kuwamura, Investigation on ultimate strength of thin-walled steel single shear bolted connections with two bolts using finite element analysis, Thin-Walled Struct, 47 (2009) 1191-1202, doi:10.1016/j.tws.2009.04.009

${ }^{26}$ T. S. Kim, H. Kuwamura, Finite element modeling of bolted connections in thin-walled stainless steel plates under static shear, Thin-Walled Struct., 45 (2007) 407-421, doi:10.1016/j.tws.2007. 03.006

${ }^{27}$ K. Fallahnezhad, A. Steele, R. H. Oskouei, Failure mode analysis of aluminium alloy 2024-T3 in double-lap bolted joints with single and double fasteners, A numerical and experimental study, Materials, 8 (2015) 3195-3209, doi:10.3390/ma8063195

${ }^{28}$ M. Rezaeifard, S. J. Salami, M. B. Dehkordi, M. Sadighi, A new nonlinear model for studying a sandwich panel with thin composite faces and elastic-plastic core, Thin-Walled Struct., 107 (2016) 119-137, doi:10.1016/j.tws.2016.06.012

${ }^{29}$ U. K. Mallela, A. Upadhyay, Buckling load prediction of laminated composite stiffened panels subjected to in-plane shear using artificial neural networks, Thin-Walled Struct., 102 (2016) 158-164, doi:10.1016/j.tws.2016.01.025

${ }^{30} \mathrm{~S}$. Hassanli, B. Samali, Buckling analysis of laminated composite curved panels reinforced with linear and non-linear distribution of Shape Memory Alloys, Thin-Walled Struct., 106 (2016) 9-17, doi:10.1016/j.tws.2016.04.022

${ }^{31}$ R. P. Khandelwal, A. Chakrabarti, P. Bhargava, Effect of interfacial imperfection on bending behavior of composites and sandwich laminates by an efficient C0 FE model, Thin-Walled Struct., 82 (2014) 170-182, doi:10.1016/j.tws.2014.04.011

${ }^{32}$ Y. C. Cai, B. Young, Bearing factors of cold-formed stainless steel double shear bolted connections at elevated temperatures. ThinWalled Struct., 98 (2016) 212-229, doi:10.1016/j.tws.2015.04.021

${ }^{33}$ Y. H. Cho, T. S Kim, Estimation of ultimate strength in single shear bolted connections with aluminum alloys (6061-T6), Thin-Walled Struct., 101 (2016) 43-57, doi:10.1016/j.tws.2015.11.017

${ }^{34}$ B. Pan, Y. Shi, Y. Wang, The effect of yield-to-ultimate ratio on the bolted connection under static shear, J. Shenyang Jianzhu Univ., 28 (2012), 501-506, doi:10.13614/j.cnki.11-1962/tu.2012.09.024

${ }^{35}$ GB/T3098.6-2014: Mechanical properties of fasteners-stainless steel bolts, screws and studs, China 